九州大学学術情報リポジトリ

Kyushu University Institutional Repository

\title{
Analysis of Critical Value of Rainfall to Induce Landslides and Debris-Flow in Mt. Bawakaraeng Caldera, South Sulawesi, Indonesia
}

\section{Hasnawir}

Laboratory of Forest Conservation, Department of Forest and Forest Product sciences, Graduate School of Bioresource and Bioenvironmnetal Sciences, Faculty of Agriculture, Kyushu University

Kubota, Tetsuya

Laboratory of Forest Conservation, Department of Forest and Forest Product sciences, Graduate School of Bioresource and Bioenvironmnetal Sciences, Faculty of Agriculture, Kyushu University

https://doi.org/10.5109/12868

出版情報: 九州大学大学院農学研究院紀要. 53 (2)，pp.523-527，2008-10-28. Faculty of Agriculture, Kyushu University

バージョン :

権利関係 : 


\title{
Analysis of Critical Value of Rainfall to Induce Landslides and Debris-Flow in Mt. Bawakaraeng Caldera, South Sulawesi, Indonesia
}

\section{HASNAWIR $^{1 *}$ and Tetsuya KUBOTA ${ }^{1}$}

\author{
Laboratory of Forest Conservation, Department of Forest and Forest Products, Graduate School of \\ Bioresource and Bioenvironmnetal Sciences, Faculty of Agriculture \\ Kyushu University, Fukuoka 812-8581 \\ (Received June 27, 2008 and accepted July 16, 2008)
}

\begin{abstract}
Mt. Bawakaraeng Caldera has been affected by tens of destructive landslide and debris-flow in recent years, triggered by rainfall episodes, which were responsible for many deaths and very important economic losses. Among the instability causes, meteorological factors are of primary importance in the Jeneberang Watershed, South Sulawesi namely the high recurrence rate of rainfall triggering landslides and debris-flow.

The cumulative rainfall method is used to reconstruct both absolute and calibrated antecedent rainfalls associated with each major landslide and debris-flow event. The critical rainfall combination (amountduration) responsible for each landslide and debris-flow event was assessed and rainfall threshold for landslide and debris-flow was calculated. Rainfall-triggered landslides and debris-flow in the study area are ruled by the function $I=86.517 D^{-0.408}$, where $I$ is the rainfall intensity in mm/day and $D$ is the duration of rainfall in days. They are related both to short duration precipitation events (1-3 days) with high average intensity (between 82 and $90 \mathrm{~mm} /$ day) and long-lasting rainfall episodes (1-5 months) with a lower intensity (between 10 and $15 \mathrm{~mm} /$ day).
\end{abstract}

\section{INTRODUCTION}

Landslides and debris-flow have become vulnerable to the nature in Indonesia in recent years. Losses of lives, destruction of properties, economic scarcities and adverse impacts to environment have been caused by these phenomena every year. According to the National Disaster Management Coordinating Board of Indonesia in 2007, landslide and debris-flow are categorized at the third number of event after flood and storm. The phenomena occurred 56 times causing, 73 people dead, 7,488 displaced and 2,685 family house destroyed.

Particularly in South Sulawesi Province natural disaster like landslide and debris-flow were important issues for mitigation especially in 2004. There occurred a large-scale landslide including debris-flow at the Mt. Bawakaraeng Caldera which had produced a volume about 232 million $\mathrm{m}^{3}$. The landslide was caused by the collapse of the walls of the caldera leading to a flow of a large amount of debris with significant damages including 32 people lost their lives and destruction of properties (Tsuchiya et al., 2004).

There are various factors affecting slope stability and some of them are closely related. Among instability causes, meteorological factors are of primary importance, namely, the control exerted on the amount of available water for infiltration into soils and rocks. Meteorological and climatic factors may act as pre-disposing factors within the slope instability system, but more frequently they represent the ultimate cause, or

\footnotetext{
1 Laboratory of Forest Conservation, Department of Forest and Forest Product sciences, Graduate School of Bioresource and Bioenvironmnetal Sciences, Faculty of Agriculture, Kyushu University, Fukuoka 812-8581

* Corresponding author (E-mail: wirforest@yahoo.com)
}

the triggering factor, of landslide activity and debrisflow (Fukuota, 1980; Crozier, 1986; Wieczorek, 1996; Corominas, 2001; Marques, 2008).

The Mt. Bawakaraeng Caldera, the majority of landslides and debris-flow has been triggered by intense rainfall. Therefore, the main objective of this study is to discriminate precipitation events (amount/duration) responsible for landslide and debris-flow activity using empirical methodologies which might provide basis for implementation of mitigation measure.

\section{STUDY AREA}

The Mt. Bawakaraeng Caldera is located at the head of the Jeneberang Watershed, $90 \mathrm{~km}$ far from Makassar, South Sulawesi (Fig. 1). The annual rainfall and mean annual temperature according to variations of the elevation in study area (1999-2007) is shown in Fig. 2.

The morphology of Mt. Bawakaraeng is characterized by high relief, extreme slope, high degree of weathering as well as erosion activities such as soil movement and landslide. The Mt. Bawakaraeng was developed as a result of volcanic activities during the Pleistocene period. It is composed of andesite rocks such as breccia, pyroclasts, tuff and interstratified lavas (Sukamto and Supriatna, 1982). Geological Map around the Bawakaraeng Caldera is shown in Fig. 3 and geogogical strata in Table 1. In volcanic rocks near the vent, pyroclastic rocks are predominant. The composition ratio and layer thickness of lava increases near the vicinity of the vent. At the end portion, sedimentary rocks, which are secondary deposit of pyroclastic rocks and volcanic rocks, are predominant. 


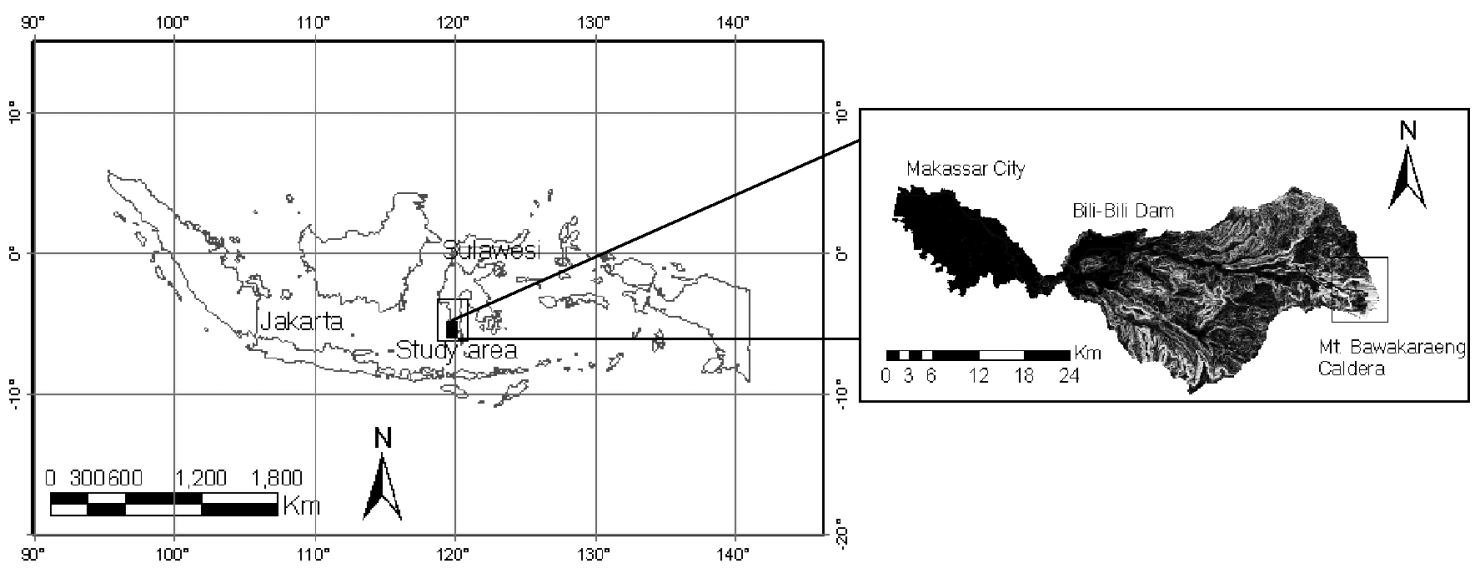

Fig. 1. Location map of the study area in Jeneberang Watershed, South Sulawesi, Indonesia.

Table 1. Geological strata around caldera

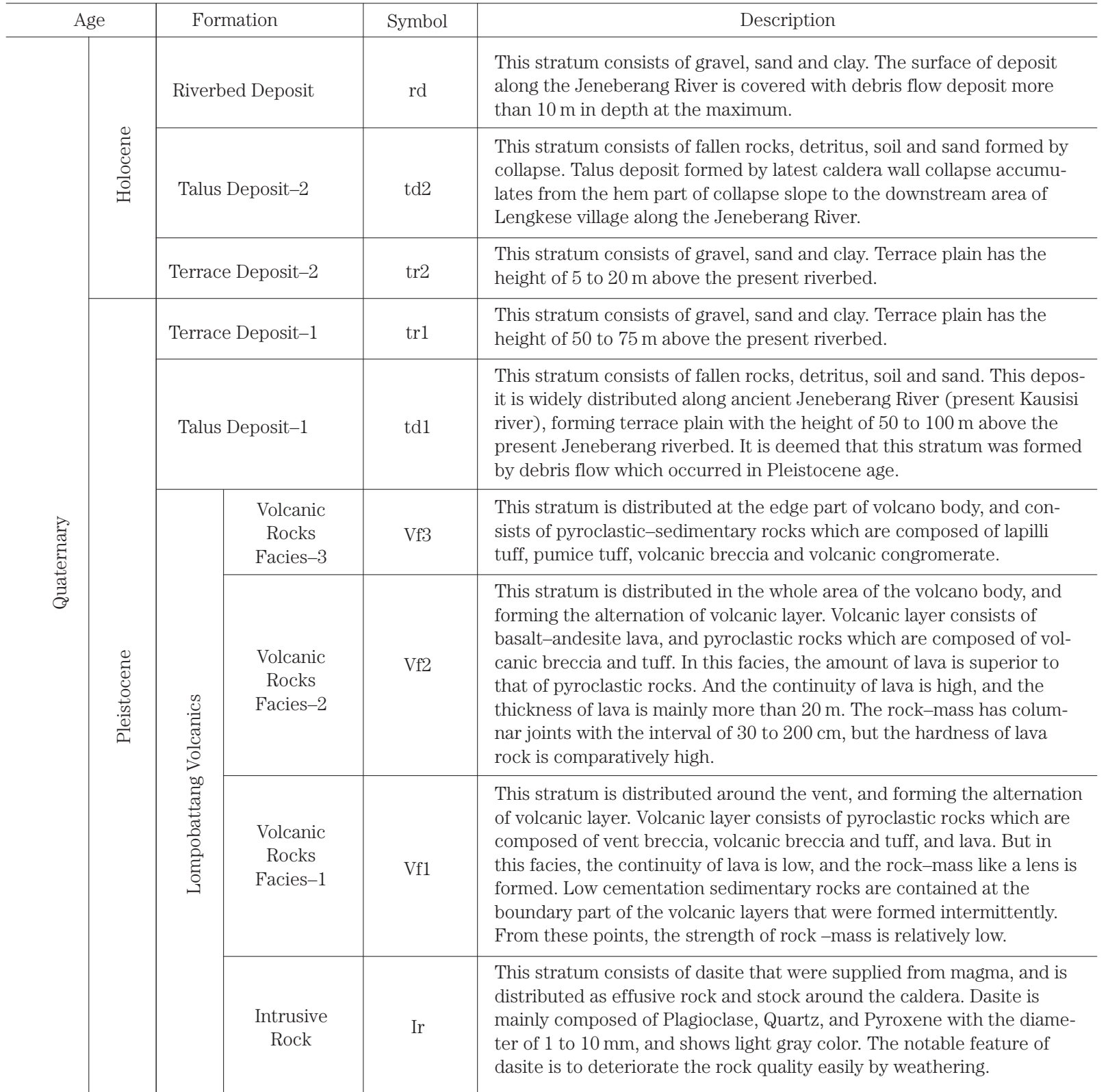




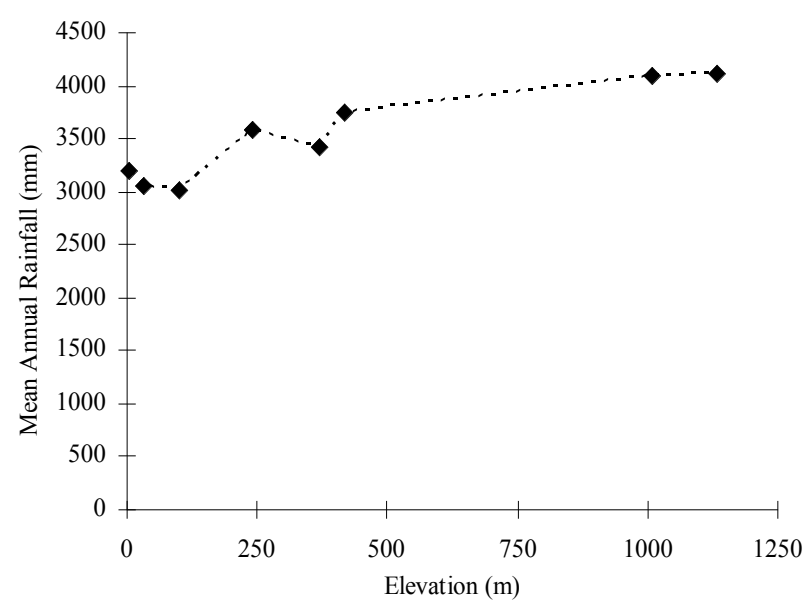

Fig. 2. The annual rainfall with the elevation of the study area, 1999-2007 (the maximum height of rain gauge is kept at an elevation of 1,134 m).

\section{RECONSTRUCTION OF THE PAST RAINFALL- TRIGGERED LANDSLIDE AND DEBRIS-FLOW EVENTS}

\section{Reconstruction of absolute antecedent rainfall}

The landslide and debris-flow occurrences used in this study were collected from historical accounts, technical-scientific documents and regional report. Pursuant to field survey and information from the local people, the landslide and debris-flow have occurred for more then ten years in the study area. Twelve major rainfall episodes that triggered landslides and debris-flow were identified.

Hence the computational analysis of the cumulative absolute rainfall for $1,2,3,5,10,15,30,40,60,75,90$, 120 and 150 consecutive days before each major landslide and debris-flow events during 1997 - 2007 have been carried out by applying following equation (Marques et al., 2008):

$$
P x=P 1+P 2+\ldots .+P n
$$

where $P x$ is the absolute antecedent rainfall for day $x$; $P 1$ is the daily rainfall for the day before $x$; $P n$ is the daily rainfall for the $n t h$ day before day $x$.

\section{Reconstruction of calibrated antecedent rainfall}

Effects of a particular rainy event decrease in time owing to drainage processes (Canuti et al., 1985; Crozier, 1986). Therefore, in order to account for this dampening effect in the rainfall-landslide analysis, the antecedent rainfall was calibrated applying the formula proposed by Crozier (1986) as shown by equation 2 :

$$
C A R x_{n}=K P 1+K^{2} P 2+\ldots .+K^{n} P n
$$

where $C A R x$ is the calibrated antecedent rainfall for day $x$; $\mathrm{P} 1$ is the daily rainfall for the day before $x$; $\mathrm{Pn}$ is the daily rainfall for the nth day before day $x$. The constant $\mathrm{K}$ is an empirical parameter (typical values range between 0.8 and 0.9 ) depending on the draining capacity and the hydrological characteristics of the area (Capecchi and Focardi, 1988). After a few tentative trials we have

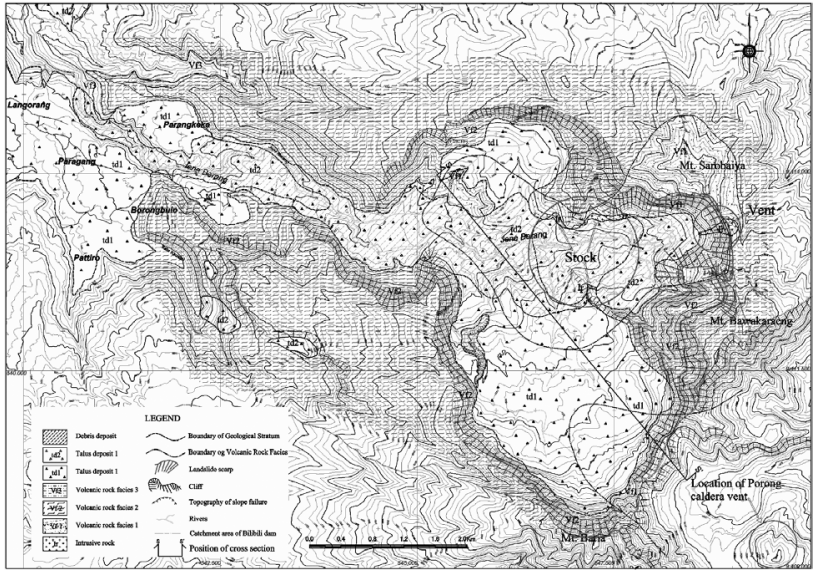

Fig. 3. Geological map around caldera (Ministry of Public Works, Indonesia, 2005)

decided to assume in this study that $\mathrm{K}=0.9$, making negligible precipitation occurred more than 30 days before a landslide event (Capecchi and Focardi, 1988). The reconstruction of calibrated antecedent rainfall was performed for time periods of $3,5,10,15$ and 30 days. Table 2 summarizes absolute antecedent rainfall for landslide and debris-flow events. Some important landslide events (e.g. event March 26, 2004) seem to be a more intense and short rainfall episode ( 3 day before) that triggers the landslide (Fig. 4). Debris-flow took place on February 16, 2007, this event was related with a more prolonged rainy period responsible for the reactivation of a deep rotational slip (Fig. 5). Table 3 summarizes results of calibrated antecedent rainfall for landslide and debris-flow events.

\section{Rainfall thresholds}

The rainfall conditions that trigger landslides and debris-flow can be different. Consider the critical pairs of rainfall amount-duration for reported landslide and debris-flow events, the regression line that relates rainfall intensity in mm/day (I) and duration of rainfall in days (D) can be plotted (Fig. 6). Therefore, the regres-

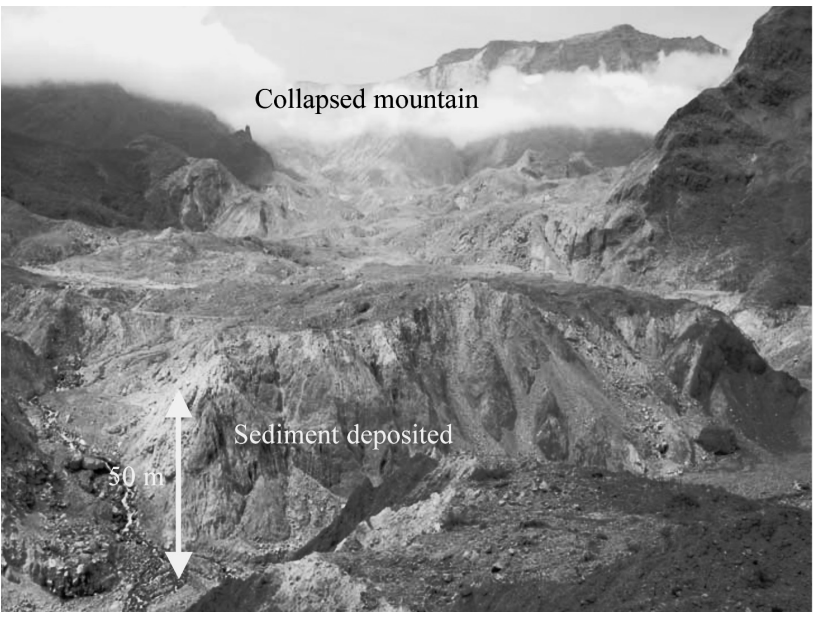

Fig. 4. Photograph representing the landslide at the Mt. Bawakaraeng Caldera, occur on March 26, 2004, hundred million $\mathrm{m}^{3}$ volume of landslide deposited in the caldera (Photo: Hasnawir, 2006) 
sion curve can be considered as a reliable rainfall intensity-duration threshold for the study area, above which, landslide or debris flow events may occur.

An empirical threshold above which landslide or debris-flow may occur can be described by next equation as below,

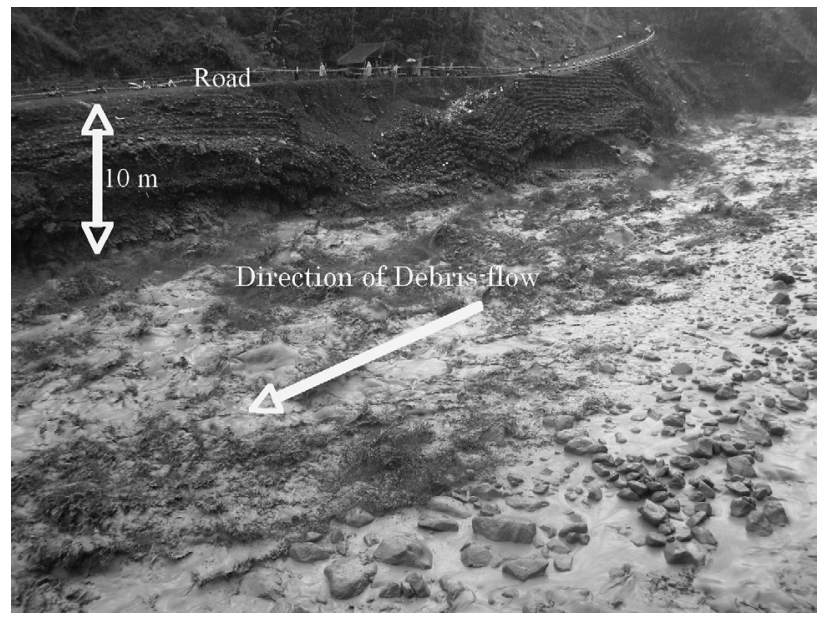

Fig. 5. Photograph revealing debris-flows occurred on 16 February 2007 (Photo: Hazama-Brantas J.O., 2007).

$$
I=86.517 D^{-0.408} \text {. }
$$

Considering only severe and disastrous events, it can be seen that there are two distinct hydrological conditions for their occurrence: (1) intense rainfall episodes in short periods (1-3 days) with high average intensity

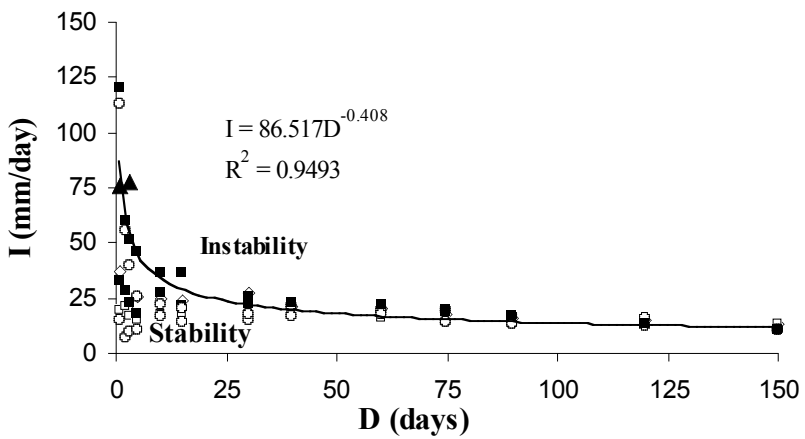

Fig. 6. Regression line between critical rainfall intensity and corresponding event duration. Legend: triangles indicate disastrous landslide events; squares indicate severe landslide-debris flow events and circles indicate minor landslide and/or debris-flow events.

Table 2. Absolute antecedent rainfall from 1 to 150 days corresponding to 12 landslides and debris-flow events verified in Mt. Bawakaraeng Caldera from 1997 to 2007

\begin{tabular}{|c|c|c|c|c|c|c|c|c|c|c|c|c|c|c|c|}
\hline No & $\begin{array}{c}\text { Date } \\
* \mathrm{R}(\mathrm{mm})\end{array}$ & 1 day & 2 days & 3 days & 5 days & $\begin{array}{c}10 \\
\text { days }\end{array}$ & $\begin{array}{c}15 \\
\text { days }\end{array}$ & $\begin{array}{c}30 \\
\text { days }\end{array}$ & $\begin{array}{c}40 \\
\text { days }\end{array}$ & $\begin{array}{c}60 \\
\text { days }\end{array}$ & $\begin{array}{c}75 \\
\text { days }\end{array}$ & $\begin{array}{c}90 \\
\text { days }\end{array}$ & $\begin{array}{c}120 \\
\text { days }\end{array}$ & $\begin{array}{l}150 \\
\text { days }\end{array}$ & $\begin{array}{c}\text { Rainfall intensity } \\
\text { (mm/day) }\end{array}$ \\
\hline 1 & 1997 Jan. 23 & 37.0 & 42.0 & 57.0 & 134.0 & 253.0 & 367.0 & 818.0 & 842.0 & 1257.0 & 1354.0 & 1500.0 & 1853.0 & 1966.0 & 37.0 \\
\hline 2 & 1999 Feb. 25 & 90.0 & 102.0 & 107.0 & 120.0 & 120.0 & 216.0 & 560.0 & 711.0 & 1177.0 & 1453.0 & 1552.0 & 1667.0 & 1874.0 & 90.0 \\
\hline 3 & 2000 Jan. 26 & 120.0 & 120.0 & 154.0 & 232.0 & 274.0 & 321.0 & 678.0 & 897.0 & 1033.0 & 1184.0 & 1312.0 & 1623.0 & 1971.0 & 82.0 \\
\hline 4 & 2001 Feb. 27 & 25.0 & 74.0 & 113.0 & 162.0 & 321.0 & 423.0 & 781.0 & 811.0 & 984.0 & 1041.0 & 1277.0 & 1672.0 & 2014.0 & 25.0 \\
\hline 5 & 2001 Feb. 25 & 19.0 & 42.0 & 51.0 & 78.0 & 180.0 & 272.0 & 569.0 & 721.0 & 992.0 & 1100.0 & 1211.0 & 1543.0 & 1976.0 & 19.0 \\
\hline 6 & 2002 Dec. 13 & 43.0 & 110.0 & 110.0 & 133.0 & 183.0 & 351.0 & 834.0 & 951.0 & 1711.0 & 1796.0 & 1813.0 & 1957.0 & 2021.0 & 37.0 \\
\hline 7 & 2003 Mar. 05 & 113.0 & 113.0 & 120.0 & 134.0 & 175.0 & 216.0 & 476.0 & 711.0 & 1177.0 & 1453.0 & 1554.0 & 1667.0 & 1874.0 & 90.0 \\
\hline 8 & 2004 Mar. 26 & 0.0 & 0.0 & 78.0 & 130.0 & 290.0 & 523.0 & 764.0 & 842.0 & 1257.0 & 1354.0 & 1500.0 & 1780.0 & 2179.0 & 0.0 \\
\hline 9 & 2005 Nov. 26 & 15.0 & 15.0 & 29.0 & 54.0 & 223.0 & 312.0 & 545.0 & 854.0 & 1082.0 & 1102.0 & 1231.0 & 1475.0 & 1782.0 & 15.0 \\
\hline 10 & 2005 Dec. 18 & 63.5 & 99.5 & 99.5 & 125.0 & 164.0 & 256.0 & 443.0 & 665.0 & 887.0 & 1056.0 & 1347.0 & 1567.0 & 1894.0 & 43.5 \\
\hline 11 & 2007 Feb. 08 & 33.0 & 56.0 & 70.0 & 90.0 & 367.0 & 554.0 & 792.0 & 940.0 & 1350.0 & 1453.0 & 1562.0 & 1621.0 & 1706.0 & 10.0 \\
\hline 12 & 2007 Feb. 16 & 110.0 & 133.0 & 139.0 & 146.0 & 183.0 & 351.0 & 834.0 & 951.0 & 1711.0 & 1796.0 & 1813.0 & 1957.0 & 2021.0 & 67.0 \\
\hline
\end{tabular}

*R: rainfall (mm).

Table 3. Calibrated antecedent rainfall (CAR) for 12 landslide and debris-flow events verified in Mt. Bawakaraeng Caldera from 1997 to 2007

\begin{tabular}{|c|c|c|c|c|c|c|c|}
\hline No & Date & $\begin{array}{l}\text { Daily rain- } \\
\text { fall } \\
(\mathrm{mm})\end{array}$ & $\begin{array}{c}3 \text { days } \\
\text { (mm) }\end{array}$ & $\begin{array}{c}5 \text { days } \\
\text { (mm) }\end{array}$ & $\begin{array}{c}10 \text { days } \\
(\mathrm{mm})\end{array}$ & $\begin{array}{l}15 \text { days } \\
\text { (mm) }\end{array}$ & $\begin{array}{c}30 \text { days } \\
(\mathrm{mm})\end{array}$ \\
\hline 1 & 1997 Jan. 23 & 37.0 & 15.0 & 60.4 & 101.1 & 126.0 & 145.1 \\
\hline 2 & 1999 Feb. 25 & 90.0 & 13.4 & 21.0 & 21.0 & 41.2 & 55.7 \\
\hline 3 & 2000 Jan. 26 & 82.0 & 59.0 & 105.0 & 119.7 & 129.6 & 144.7 \\
\hline 4 & 2001 Feb. 27 & 25.0 & 68.1 & 97.0 & 152.7 & 174.1 & 189.2 \\
\hline 5 & 2001 Feb. 25 & 19.0 & 25.2 & 41.1 & 76.8 & 96.1 & 108.7 \\
\hline 6 & 2002 Dec. 13 & 37.0 & 59.7 & 73.2 & 90.7 & 126.0 & 146.5 \\
\hline 7 & 2003 Mar. 05 & 90.0 & 25.8 & 34.1 & 48.4 & 57.0 & 68.0 \\
\hline 8 & 2004 Mar. 26 & 0.0 & 56.9 & 87.5 & 143.5 & 192.5 & 202.7 \\
\hline 9 & 2005 Nop. 26 & 15.0 & 10.2 & 25.0 & 84.1 & 102.8 & 112.7 \\
\hline 10 & 2005 Dec. 18 & 43.5 & 47.2 & 62.2 & 75.9 & 95.2 & 103.1 \\
\hline 11 & 2007 Feb. 08 & 10.0 & 49.5 & 61.3 & 158.3 & 197.6 & 207.6 \\
\hline 12 & 2007 Feb. 16 & 67.0 & 61.7 & 65.8 & 78.8 & 114.1 & 134.5 \\
\hline
\end{tabular}


(between 82 and $90 \mathrm{~mm} /$ day) and (2) precipitation accumulated during longer periods (1-5 months) with a lower rainfall intensity (between 10 and $15 \mathrm{~mm} /$ day).

\section{CONCLUSIONS}

1. Historical accounts and recent observations show that rainfall-induced landslides and debris-flow are frequent in Mt. Bawakaraeng Caldera, Jeneberang Watershed.

2. The hydrological conditions are traced by landslide and debris-flow activity triggered by short periods of rainfall accumulation (1-3 days), characterized by high average intensity (between 80 and $90 \mathrm{~mm} /$ day) and long-lasting rainfall episodes (1-5 months) with a lower intensity (between 10 and $15 \mathrm{~mm} /$ day).

3. The regression analysis shows that rainfall intensity increases exponentially as duration decreases, following the equation $I=86.517 D^{-0.408}$, where $I$ is the rainfall intensity in $\mathrm{mm} /$ day and $D$ is the duration of rainfall in days. Therefore, the regression can be considered as a reliable rainfall intensity-duration threshold for the study area, above which, landslide and/or debris-flow events may occur.

\section{REFERENCES}

Canuti, P., Focardi, P. and Garzonio, C. A. 1985. Correlation between rainfall and landslides. Bulletin of the International
Association Engineering Geology, 32: 49-54

Capecchi, F. and Focardi, P. 1988. Rainfall and landslides: research into a critical precipitation coefficient in an area of Italy. In Landslides, Proceedings of the Fifth International Symposium Landslides, Bonnard C (ed). Balkema: Roterdam; 1131-1136

Corominas, J. 2001. Landslides and climate. In Keynote Lectures from the 8th International Symposium on Landslides, vol. 4, Telford T (ed). Cardiff, Galles; 1-33

Crozier, M. 1986. Landslides: Causes, Consequences and Environment. Croom Helm; London, 252

Fukuota, M. 1980. Landslides associated with rainfall. Geotechnical Engineering, 11: 1-29

Marques, R., Zêzere, J., Trigo, R., Gaspar1, J., and Trigo, I., 2008. Rainfall patterns and critical values associated with landslides in Povoação County (São Miguel Island, Azores): relationships with the North Atlantic Oscillation. Hydrological Process, 22 478-494

Ministry of Public Works Indonesia 2005. Bawakaraeng urgent sediment control project (unpublished)

Sukamto, R. and Supriatna, S., 1982. Geological Map of the Ujung Pandang, Bantaeng and Sinjai Quadrangles, Sulawesi. Geological Research and Development Centre, Bandung, Indonesia

Tsuchiya, S., Koga, S., Sasahara, K., Matsui, M., Nakahiro, M., Watanabe, F., Shima, H., and Yoshida, K., 2004. Reconnaissance of the gigantic landslide occurred on Mt. Bawakaraeng in the south Sulawesi state of Indonesia and unstable debris sedimentation (prompt report). Journal of the Japan Society of Erosion Control Engineering, 57(3): 40-46

Wieczorek, G. F. 1996. Landslide triggering mechanisms. In Landslides: Investigation and Mitigation. Turner, A. K., Shuster, R. L. (eds). Transportation Research Board-National Research Council: Special Report 247, Washington DC; 76-90 